\title{
MAKNA KEGIATAN UNILEVER FUTURE LEADERS LEAGUE BAGI PARA PESERTA
}

(Studi Fenomenologi tentang Makna Kegiatan Unilever Future Leaders League sebagai Employer Branding PT Unilever Indonesia Tbk bagi Para Peserta)

\section{Gede Adi Wiswa Mitra Artawan, Evie Ariadnes Shintadewi, dan Heru Ryanto Budiana Prodi Humas, Fikom Unpad, J1. Raya Bandung-Sumedang Km. 21 Jatinangor \\ Email: heru.prodihumas@gmail.com}

\begin{abstract}
ABSTRAK
Latar belakang penelitian ini adalah dimana peneliti menemukan fenomena di dalam sebuah kompetisi bisnis yang bernama Unilver Future Leaders League, dimana para peserta yang pada awalnya memiliki motif yang sedemikian rupa, dengan tujuan atau harapan awal mereka untuk mengikuti UFLL, menjadi berbeda setelah mereka selesai mengikuti kompetisi ini dimana peserta akhirnya tertarik untuk bergabung lebih lanjut dengan Unilever sebagai karyawanmereka, meskipun tidak ada ajakan langsung dari Unilever untuk bergabung menjadi karyawan selama UFLL berlangsung. Peneliti disini menarik benang merah dimana UFLL tentu memiliki makna tersendiri bagi setiap individu peserta.

Penelitian ini bertujuan untuk mengetahui makna kegiatan Unilever Future Leaders League oleh para peserta. Teori Fenomenologi Alfred Schutz digunakan sebagai landasanteori dalam penelitian ini. Metodologi yang digunakan yaitu kualitatif dengan teknikpengumpulan data berupa observasi, wawancara, dan studi pustaka. Adapun key informan di dalam penelitian ini adalah para peserta dari kompetisi UFLL. Hasil dari penelitian ini adalah kegiatanUnilever Future Leaders League terbagi menjadi dua makna, makna UFLL sebagai kompetisi dan makna UFLL sebagai peluang unutk meneruskan karir di Uinlever. UFLL sebagai kompetisi dimaknai oleh para peserta sebagai sarana transformasi diri, tempat pembentukkan karakter dan langkah awal untuk bekerja di Unilever. Sedangkan makna UFLL sebegai peluang meneruskna karir di Unilever terbagi menjadi makna afirmatif, makna relatif dan makna negatif.

Kesimpulan dari penelitian ini adalah dimana makna yang terdapat dalam setiap individu informan terbentuk dari pengalaman mereka selama mengikuti berbagai kegiatan di dalam kompetisi UFLL dan hasil saling bertukar makna dengan sesama peserta. Saran peneliti adalah sebaiknya Unilever memberikan wadah atau lebih mengorganisir para peserta yang telah selesai mengikuti Unilever Future Leaders League sesuai dengan tujuan awal Unilever yaitu untuk menjadikan mereka ambassador dari Unilever.Selain itu Unilever sebaiknya melakukan follow up kepada peserta sehingga nantinya peserta yang ingin melanjutkan karir ke Unilever dapat terakomodasi. Terakhir adalah sebaiknya Unilever memberikan kegiatan khusus dengan tema kepemimpinan sehingga benang merah dari kegiatan ini tetap terjaga.
\end{abstract}

Kata Kunci: Makna, Kompetisi Bisnis, Employer branding, Unilever.

\section{MEANING OF UNILEVER FUTURE LEADERS LEAGUE ACTIVITES FOR PARTICIPANTS}

(Phenomenology Study on Meaning of Unilever Future Leaders League Activites as Employer Branding PT Unilever Indonesia Tbk for The Participants)

\begin{abstract}
The background of this study is that researchers discovered the phenomenon in a business competition named Unilever Future Leaders League, where participants who initially had motives in such a way, with the purpose or hope their early to follow UFLL, be different after they finished the competition where the participant ultimately more interested in joining with Unilever as their employees, even though there is no direct invitation from Unilever to join the employee during UFLL progress. Researchers here draw a red thread where UFLL certainly has significance for each individual participant.

This study aims to determine the meaning of the activities of Unilever Future Leaders League by the participants. Theory Phenomenology of Alfred Schutz was used as the theoretical basis of this research. The methodology used is qualitative data collection techniques such as observation, interview, and literature study. The key informants in this study were the participants of the competition UFLL.
\end{abstract}


Results from this study are activities of Unilever Future Leaders League is divided into two meanings, significance and meaning UFLL as UFLL competition as an opportunity to continue a career in Uinlever fatherly. Competition UFLL as interpreted by the participants as a means of self-transformation, the formation of character and the first step to work at Unilever. While the meaning of UFLL sebegai meneruskna career opportunities at Unilever divided into affirmative meaning, meaning relative and negative meaning.

The conclusion from this study is that the meaning contained in each individual informant formed from their experiences during the various activities in UFLL competition and results exchanged meanings with fellow participants. Researchers are Unilever advice should provide containers or organize the participants who completed follow Unilever Future Leaders League in accordance with the original purpose of Unilever is to make them ambassadors of Unilever. Additionally Unilever should follow up to the participants so that later the participants who wish to pursue a career to Unilever can be accommodated. Unilever latter is preferably give specific activities on the theme of leadership so that the common thread of this activity is maintained.

Key word: Meaning, Business competition, Employer branding, Unilever.

\section{PENDAHULUAN}

Unilever Future Leaders League Indonesia (selanjutnya akan disebut UFLL) merupakan kompetisi tingkat nasional yang cukup unik dalam membangun jiwa kepemimpinan dan menumbuhkan jiwa enterpreneurship bagi para pesertanya. Sesuai dengan tujuan dari UFLL untuk membangun jiwa kepemimpinan kepada peserta, adapaun definisi dari kepemimpinan adalah proses memengaruhi atau memberi contoh oleh pemimpin kepada pengikutnya dalam upaya mencapai tujuan organisasi. Cara alamiah mempelajari kepemimpinan adalah melakukannya dalam kerja dengan praktik seperti pemagangan pada seorang seniman ahli, pengrajin, atau praktisi. Dalam hubungan ini sang ahli diharapkan sebagai bagian dari peranya memberikan pengajaran atau instruksi. Pada konteks penelitian ini, UFLL akan memberikan pelatihan kepada para peserta melalui mentor dari pihak Unilever Indonesia yang dimana dalam pelatihan tersebut para peserta akan diajarkan dan diperlihatkan secara nyata mengenai bisnis yang dijalankan oleh Unilever. Peserta pun akan menerapkan secara langsung hasil dari pelatihan tersebut dalam kasus-kasus bisnis yang diberikan oleh Unilever.

Terdapat berbagai individu dari daerah dan universitas yang berbeda-beda yang saling berinteraksi selama kompetisi UFLL berlangsung dan dengan motif yang beragam untuk mengikuti UFLL, baik itu karena manfaat-manfaat yang ingin didapatkan setelah mengikuti UFLL ataupun hal lain. Meskipun dalam lima hari UFLL mereka masih dalam masa perkuliahan atau terlibat dalam kegiatan lain, namun mereka memilih untuk mengikuti
UFLL yang mungkin berada jauh dari kota asal mereka.

"Motivasi utama buat gue untuk ikut UFLLadalah untuk menantang diri sendiri, apakah saya dapat berprestasi di skala nasional seperti ini. Di UFLL, saya benarbenar ditantang dari berbagai macam aspek, dan hal ini membuat saya mengalami perkembangan yang sangat pesat menurut saya. Salah satu hal yang paling saya cherish adalah networking dengan teman-teman dari seluruh Indonesia di UFLL yang masih aktif sampai sekarang"1

Salah satu peserta yang peneliti temui ketika pra-riset adalah Sony Radhityo (20) atau biasa dipanggil Sony. Sony merupakan seorang mahasiswa Fakultas Ekonomie Universitas Indonesia. Sebelumnya Sony hanya lah seorang mahasiswa yang tidak pernah mempunyai pengalaman kompetisi sebelumnya. Setelah mendengar informasi menegenai UFLL, ia memutuskan untuk mendaftar dan akhirnya terpilih menjadi satu dari 30 peserta UFLL. Lalu ia menceritakan motif nya untuk mengikuti UFLL.

Mahasiswa yang ingin mengikuti UFLL tidak dibatasi dari jurusan tertentu, mahasiswa dengan program studi apapun dapat menjadi peserta karena nantinya akan diadakan proses seleksi dari pihak Unilever dan proses seleksi itu lah yang memutuskan apakah calon peserta dapat mengikuti kompetisi ini atau tidak. Seperti yang peneliti temukan di lapangan bahwa Ratih Siahaan (20) atau yang biasa dipanggil Ratih merupakan seorang mahasiswa Teknik Elektro Institut Teknologi Bandung yang berhasil menjadi peserta UFLL.

1. Dikutip dari hasil wawancara pra-riset dengan Sony 22 April 2014 
"Kalau gue pribadi baru menyadari gue kurang exposure luar ITB, padahal gue udah memasuki tingkat akhir gue terus pengalamannya masih ngerasa kurang kalo di ITB doang, makanya gue apply buat UFLL, terus dari yang gue liat di penjelasan webnya juga UFLL terlihat rewarding banget soalnya dibilang kan bakal dapet banyak coaching. Jadi gue pikir pasti pembelajaran yang gue dapet juga luar biasa harusnya. Terus lagi tertarik sama yang berbau bisnis, tapi ilmu gueengga ada, makanya karena ufl menawarkan banyak pembelajaran tentang business process makanya gue tertarik dan rela ngorbanin kuliah seminggu."

Ia mengungkapkan salah satu alasan mengapa ia ingin mengikuti kompetisi ini adalah berdasarkan pengalamannya sehari-hari nya. Ia yang notabene adalah mahasiswi teknik elektro di sebuah perguran tinggi negeri di Bandung, merasa kurang tau dunia di luar kampusnya. Selain itu ia juga tertarik dengan dunia bisnis, namun ilmu maupun pengetahuan yang ia miliki masih dianggap kurang olehnya, maka dari itu ia ingin mendapatkan pembelajaran mengenai bisnis melalui UFLL. Lalu ia juga tertarik dengan penawaran dari apa yang akan ia dapat selama mengikuti UFLLdari situs resmi kompetisi tersebut.

Sony dan Ratih hanya merupakan dua dari beberapa mahasiswa yang berhasil menjadi peserta dari UFLL. Masih ada sekian belas peserta lainnya yang mempunyai motif dan pengalaman yang mungkin berbeda-beda. UFLL yang notabene merupakan sebuah kompetisi bisnis, pada kenyataan nya ada misi tersendiri dari pihak Unilever, yang dimana UFLLmerupakan salah satu bentuk employer branding yang dilakukan oleh Unilever.

"Tujuan bagi perusahaan dalam membuat kompetisi UFLL ini juga merupakan salah satu bentuk employer branding kita. Karena company with strong employer branding will be easier to attract top talent dan itu penting untuk perusahaan kita"3

Irma Erinda mengatakan bahwa para peserta diajarkan untuk mengenal Unilever secara lebih dalam melalui acara-acara yang

2 Dikutip dari hasil wawancara pra-riset dengan Ratih 22 April 2014 3 Wawancara dengan Irma, Leadership and Development Manager, Human Resource Function PT Unilever Indonesia 7 April 2015 dikemas dengan seunik mungkin yang terdapat dalam kompetisi UFLL dan nantinya para peserta dapat menceritakan pengalaman-pengalaman mereka selama mengikuti UFLL kepada rekanrekan di kampus nya.

"Menurut gue sih acaranya wow banget. Life changing banget, bermanfaat kontenkontennya, mengenal diri sendiri lebih baik lagi, kapan lagi bisa dapat mentoring dari senior brand manager, top dan mid level Unilever Indonesia, office tour, tau dan ikut langsung di aktivitas real business FMCG yang dijalanin perusahaan terkemuka di Indonesia dari setiap divisi di Unilever. Kalau ditanya tertarik untuk intern disana sih jelas gue tertarik banget kak buat ngerasain langsung bagaimana atmosphere di dalam kegiatan perusahaan mereka."4

Melalui kutipan wawancara dengan salah satu peserta bernama Avi Bellerizki diatas dapat dilihat bagaimana pengalaman yang ia alami saat mengikuti kompetisi UFLL, serta bagaimana ia dapat mengenal baik itu budaya perusahaan, para karyawan dan budaya Unilever secara lebih dalam, sehingga membuat ia tertarik untuk bergabung dengan Unilever lebih lanjut.

"Sebenarnya ayah dan kakek saya itu kebetulan enterpreuner, dan saya sering terlibat dalam usaha yang mereka jalankan, oleh sebab itu sedikit banyak saya tau bagaimana cara berinteraksi dengan karyawan ataupun melihat karyawan saling berinteraksi. Saya ingin mengikuti jejak mereka sebagai wiraswasta, namun setelah semua yang saya dapat dan saya rasakan di UFLL, fortunately $i$ really love to see how it is works in Unilever. Saya gapernah melihat lingkungan kerja sebagus di Unilever dan saya tertarik untuk merasakan langsung." 5

Setelah mewawancarai Avi, ada satu hal yang peneliti tangkap dari para peserta UFLL, maka peneliti melakukan pra-riset lainnya dengan peserta bernama Arasyan. Disini peneliti menemukan fenomena dimana para peserta yang pada awalnya memiliki motif yang sedemikian rupa, dengan tujuan atau harapan awal mereka untuk mengikuti UFLL, menjadi berbeda setelah mereka selesai mengikuti kompetisi ini dimana peserta akhirnya tertarik untuk bergabung lebih lanjut dengan Unilever sebagai karyawanmereka, meskipun tidak ada ajakan langsung dari

4 Wawancara dengan Avi Bellerizki 24 April 2014 5 Wawancara dengan Arasyan Albar 24 April 2014 
Unilever untuk bergabung menjadi karyawan selama UFLL berlangsung. Melihat fenomena diatas, peneliti disini menarik benang merah dimana UFLL tentu memiliki makna tersendiri bagi setiap individu peserta.Hal tersebutlah yang menarik minat dari peneliti untuk mengetahui lebih jauh bagaimana makna UFLL bagi para pesertanya.

\section{KAJIAN PUSTAKA}

Salah satu tokoh yang memberikan pemikirannya dakam fenomenologi adalah Alfred Schutz. Schutz mengawali pemikirannya dengan mengatakan bahwa objek penelitian ilmu sosial padadasarnya berhubungan dengan interpretasi terhadap realitas. Dalam melakukan penelitian, peneliti harus menggunakan metode interpretasi yang sama dengan orang yang diamati, sehingga peneliti bisa masuk ke dunia interpretasi orang yang dijadikan objek penelitian.

Pemikiran fenomenologi bukan merupakan sebab gerakan pemikiran yang koheren. Ia mungkin lebih merefleksikan pemikiran dari beberapa filsuf, termasuk di dalamnya Edmund Husserl, Maurice Merleu Ponty, Martin Heidegger dan Alfred Schutz. Peneliti pada penelitian ini merujuk pada Alfred Shutz yang sering disebut fenomenologi sosial. Alfred Shutz telah mempunyai pengaruh kerja dalam ilmuwan sosiologi dan komunikasi. Schutz menerima banyak prinsip dasar yang dibangun Husserl, kecuali penundaan atas kehidupan dunia agar kemurnian dapat diperoleh. Dia membahas cara-cara agar intersbujektivitas kehidupan dunia dapat didekati dan dipahami. Menurut, Schutz, keseharian kehidupan dunia ini dapat dipahami dalam term-term yang kemudian disebutnyasebagai pelambangan atau penipean (typications) yang digunakan untuk mengorganisasikan dunia sosial.

Penipean (typications) ini adalah konstruk interpretasi yang berubah-ubah berdasarkan latar kehidupan seseorang, kelompok budayanya, dan konteks sosial tertentu. Schutz melihat penipean ini seperti diorganisasikan ke dalam sebuah ketersediaan pengetahuan yang luar biasa kompleks dan dia percaya bahwa penggambaran dari pemahaman ketersediaan pengetahuan adalah tugas utama penelitian sosial.

Peneliti dalam pandangan fenomeno-logis berusaha memahami arti peristiwa dan kaitan kaitannya terhadap orang-orang biasa dalam situasi-situasi tertentu. Sosiologi fenomenologis pada dasarnya samgat dipeng-aruhi oleh Edmund Husserl dan Alfred Schutz. Pengaruh lainnya berasal dari Weber yang memberi tekanan pada verstehn, yaitu pengertian interpretatif terhadap pemahaman manusia. Fenomenologi tidak berasumsi bahwa peneliti mengetahui arti sesuatu bagi orang-orang yang sedang diteliti oleh mereka. Fenomenologi adalah salah satu tradisi intelektual utama yang telah mempengaruhi riset kualitatif. Fenomenologi bukan hanya melihat pada perspektif partisipan, fenomenologi juga menawarkan semacam cara untuk memahami kerangka yang telah dikembangkan oleh masingmasing individu dari waktu ke waktu, sehingga membentuk tanggapan mereka terhadap peristiwa dan pengalaman kehidupannya.

Penelitian ini berupaya untuk mempelajari bagaimana peserta UFLL mengalami fenomena dalam kegiatan UFLL. Penelitian ini juga berupaya untuk memahami bagaimana fenomena tersebut dialami oleh peserta UFLL, tanpa memperhatikan baik dan buruk atau benar dam salah fenomena tersebut.

Pada intinya fenomenologi berusaha menggambarkan makna dari pengalaman hidup dari beberapa individu menganai konsep fenomena yang dialami orang-orang tertentu. Fenomonologi adalah gagasan mengenai dunia kehidupan, pemahaman bahwa realitas masing-masing individu itu berbeda, dan bahwa tindakan masingmasing individu hanya dapat dipahami melalui pemahaman terhadap dunia kehidupan individu, sekaligus melalui perspektif mereka bersama, dalam hal ini peneliti mengakses individuindividu peserta dengan tujuan mencari makna, motif-motif, tindakan, dan dunia sosial mereka dari sudut pandang mereka. Terhadap "masa yang akan datang dan harapannya" ataupun "alasan masa lalu yang mengakibatkan mereka tertarik mengikutiUnilever Future Leaders League."

Manusia tidak pasif dalam menerima rangsangan stimuli, sebaliknya manusia aktif berinteraksi dan merespon suatu pesan dalam memaknai suatu objek atau fenomena. Dalam prosesnya, ketika seseorang menerima suatu pesan, ia akan menyeleksi serta menyusun dan menafsirkannya, yang pada akhirnya ia memberi makna pada suatu objek atau peristiwa. Makna adalah penyampaian peng-alaman seseorang kepada masyarakat. 
Hasanudin dan Ruhiyat (2006) dalam bukunya Budaya, Bahasa, Semiotika, sebuah catatan kecil menuliskan. Makna adalah arti atau maksud. Kridalaksana mengartikan makna sebagai maksud pembicara (komunikator), pemahaman persepsi atau perilaku manusia atau kelompok manusia, hubungan dalam arti kesepadanan antara bahasa dan alam di luar bahasa. Djadjasudarma memberi pengertian makna adalah pertautan yang ada diantara unsurunsur itu sendiri. Sedangkan menurut Keraf, makna diartikan sebagai bentuk antara hubungan antara bentuk dengan hal atau barang yang diwakilinya.

Ada tiga hal yang coba dijelaskan oleh para filsuf dan linguis sehubungan dengan usaha menjelaskan makna dalam proses komunikasi. Ketiga hal tersebut yaitu :pertama menjelaskan makna atau kata secara alamiah, kedua mendeskripsikan kalimat secara alamiah, ketiga menjelaskan makna dalam proses komunikasi. Kempson dalam Sobur (2009:256). Makna dapat pula digolongkan ke dalam: makna denotatif dan makna konotatif. Makna denotatif adalah makna yang sebenarnya (faktual), seperti yang kita temukan dalam kamus. Karena itu, makna denotatif lebih bersifat publik. Sejumlah kata bermanka denotatif, namun banyak kata juga bermakna konotatif, lebih bersifat pribadi, yakni makna di luar rujukan objektifnya. Dengan kata lain, makna konotatif lebih bersifat subjektif dan emosional daripada makna denotatif. (Mulyana, 2007:282)

Employer Branding adalah suatu strategi mengenai cara suatu organisasi sebagai pemberi kerja dapat berkomunikasi serta berinteraksi kepada calon karyawan, karyawan dan kepada pihak luar baik itu dulu, sekarang dan juga di masa yang akan dating. Menurut Ambler and Barrow (1996), Employer Branding adalah paketfungsional, ekonomi dan manfaat psikologi yang diberikan oleh perusahaan dan diidentifikasi oleh merek perusahaan itu sendiri. Definisi lainmenurut Minchington, employer branding berkaitan dengan citra sebuah organisasi sebagai tempat kerja yang menyenangkandalam benak karyawan serta pemangku kepentingan utama dari pihak eksternal seperti pelanggan dan calon karyawan. Employer branding juga bertujuan untuk meyakinkan talenta-talenta potensial agar mau bekerja dalam sebuah perusahaan, mengurangi tingkat keluar masuk, meningkatkan motivasi, dan rasa memiliki karyawan.

Unilever Future Leaders League (selanjutnya disebut UFLL) adalah kompetisi bisnis khususnya dalam bidang fast moving consumer goods yang pertama kali diluncurkan oleh Unilever di Indonesia, kompetisi bisnis global yang diselenggarakan oleh Unilever ini diikuti oleh 30 peserta yang merupakan mahasiswa dari berbagai universitas di Indonesia.Unilever Future Leaders League merupakan kompetisi yang cukup unik dalam membangun jiwa kepemimpinan dan menumbuhkan jiwa enterpreneurship bagi para pesertanya. Sebanyak 30 anak muda yang merupakan mahasiswa dari universitas di Indonesia akan bergabung dalam kompetisi bergengsi tingkat nasional untuk memenangkan juara pertama. Sebanyak 30 peserta yang sudah diseleksi selanjutnya akan mengikuti U-Camp dan akan dibagi menjadi 10 kelompok yang beranggotakan tiga orang yang dimana juara nya akan mewakili Indonesia dalam kompetisi UFLL global.

Leadership atau kepemimpinan berasal dari kata leaders atau pemimpin, pemimpin adalah seorang individu yang menuntun, mengatur, memotivasi atau menginspirasi orang lain. Mereka adalah pria atau wanita yang mempengaruhi orang lain di dalam sebuah organisasi atau komunitas tertentu. Deborah J Barret (2008) dalam bukunya Leadership Communication mengatakan bahwa kepemimpinan dan komunikasi merupakan dua hal yang saling berhubungan. Tanpa adanya komunikasi yang efektif, sorang pemimpin tidak dapat mencapai tujuannya dengan baik. Tanpa komunikasi yang efektif, seorang pemimpin tidak akan efektif.

Definisi lain dari kepemimpinan adalah adalah proses memengaruhi atau memberi contoh oleh pemimpin kepada pengikutnya dalam upaya mencapai tujuan organisasi. Cara alamiah mempelajari kepemimpinan adalah melakukannya dalam kerja dengan praktik seperti pemagangan pada seorang seniman ahli, pengrajin, atau praktisi. Dalam hubungan ini sang ahli diharapkan sebagai bagian dari peranya memberikan pengajaran atau instruksi. Pada konteks penelitian ini, UFLL akan memberikan pelatihan kepada para peserta melalui mentor dari pihak Unilever Indonesia yang dimana dalam pelatihan tersebut para 
peserta akan diajarkan dan diperlihatkan secara nyata mengenai bisnis yang dijalankan oleh Unilever. Peserta pun akan menerapkan secara langsung hasil dari pelatihan tersebut dalam kasus-kasus bisnis yang diberikan oleh Unilever.

\section{METODE}

Metode penelitian yang digunakan dalam penelitian ini adalah metode penelitian kualitatif. Teknik pengumpulan data mengunakan wawancara mendalam, dan pengamatan. Menurut Kirk dan Miller (1986) bahwa penelitian kualitatif adalah tradisi tertentu dalam ilmu pengetahuan sosial yang secara fundamental bergantung dari pengamatan pada manusia baik dalam kawasannya walaupun dalam peristilahannya. (Moleong 2009:4)

Apabila ditelusuri, peneliti menggunakan metode penelitian kualitatf dalam penelitian ini karena peneliti ingin memahami dan menjelaskan makna kegiatan Unilever Future Leaders League bagi pesertanya itu sendiri. Hal ini bertujuan karena penelitian kualitatif mempersoalkan makna berada di kedalaman dan mempertanyakan fenomena. Makna tersebut akan didapatkan peneliti dengan wawancara dengan informan secara mendalam yang dimana hal tersebut tidak bisa didapat dengan penelitian kuantitatif karena perspektif setiap individu informan berbedabeda. Selain wawancara mendalam, peneliti juga mengobservasi langsung kegiatan para peserta UFLL selama kompetisi tersebut berlangsung.

Studi penelitian yang digunakan dalam penelitian ini adalah studi Fenomenologi. Fenomenologi adalah sebuah studi dalam bidang filsafat yang memelajari manusia sebagai sebuah fenomena. Ilmu fenomenologi dalam filsafat biasa dihubungkan dengan Ilmu Hermeuntik, yaitu ilmu yang memelajari arti dari pada fenomenologi. Begitu pun dalam penelitian ini mencoba untuk mempelajadi fenomena manusia yang tergabung menjadi peserta dari sebuah kompetisi bisnis yang diadakan oleh sebuah perusahaan Unilever. Dimana kompetisi bisnis ini merupakan bentuk employer branding perusahaan mereka dan secara tidak langsung membangun jiwa kepemimpinan dari para peserta melalui kegiatan-kegiatan di dalamnya.
Studi feno-menologi mempelajari pengalaman subjektif dari maunsia dan studi kesadaran atau perspektif dari seseorang. Dalam penelitian ini, seseorang manusia atau individu yang dimaksud adalah peserta dari kegiatan UFLL. Setiap peserta memiliki pengalaman komunikasi dan juga perspektif sendiri selama mengikuti kegiatan UFLL, oleh karena itu mereka tentu memiliki makna sendiri mengenai UFLL.

Kuswarno (2009:39) menuliskan, Schutz membuat model tindakan manusia melalui proses yang dinamakan "tipikasi". Konsep tipikasi ini merupakan penggabungan Schutz terhadap pemikiran-pemikiran Weber dan Husserl. Adapun jenis tipikasi bergantung pada orang yang membuatnya, sehingga kita dapat mengenal tipe aktor, tipe tindakan, tipe kepribadian sosial, dsb. Bagi Schutz, jenis tipikasi dibuat berdasarkan kesamaan tujuan, namun dalam struktur yang relevan dengan tujuan peneltian. Singkatnya tipikasi ini menyediakan seperangkat alat identifikasi, kla-sifikasi, dan model perbandingan dari tindakan dan interaksi sosial. Dengan menggunakan kriteria yang telah didefinisikan untuk penempatan fenomena ke dalam tipe-tipe khusus. Dalam penelitian ini, peneliti membuat tipikasi dari hasil 3 pertanyaan penelitian yaitu, tipikasi makna, motif, dan pengalaman mengenai UFLL.

\section{HASIL DAN PEMBAHASAN}

Unilever Future Leaders League memiliki berbagai macam makna yang disampaikan oleh peserta nya. Makna tersebut disampaikan dengan gaya bahasa dan pernyataan mereka masing-masing. Selain itu setiap peserta UFLL juga memiliki motif mereka masing-masing untuk mengikuti kegiatan UFLL yang kemudian motif tersebut peneliti kategorikan ke dalam dua kategori yaitu motif sebab (because of motives) dan motif untuk (in order to motives). Kemudian pengalaman peserta mengenai kegiatan UFLL dibagi kepada 2 fase pengalaman, yaitu fase sebelum bergabung dalam komunitas dan fase setelah begabung dalam komunitas dan manfaat dari pengalaman mereka mengikuti kegiatan UFLL.

\section{Makna UFLL}

Makna yang didapat oleh para narasumber terbentuk karena adanya konstruksi yang ter- 
jadi dalam benak masing-masing individu. Aspek-aspek yang mempengaruhi adalah motif yang mendorong perilaku komunikasi dan pengalaman para peserta UFLL. Berdasarkan hasil wawancara dan observasi dari peneliti, ditemukan bermacam-macam makna yang disampaikan oleh para informan mengenai UFLL. Selain itu, peneliti juga mencoba menggali makna mengenai Unilever yang merupakan perusahaan dibelakang kompetisi UFLL. Unilever tentunya memiliki misi atau tujuan yang baik itu secara tersirat maupun secara tersurat disampaikan langsung kepada para peserta UFLL. Salah satu bentuk sederhananya adalah saat perusahaan membentuk suatu makna mengenai Unilever akan sama dengan bagaimana para peserta memaknainya. Seperti yang sudah peneliti ungkapkan bahwa UFLL ini merupakan salah satu bentuk employer branding mereka.

"Employer Branding itu dasarnya melihat perusahaan sebagai suatu brand untuk memastikan kita bisa menarik talentatalenta terbaik unutk memudahkan kita untuk menarik talenta tersebut, karena bagaimanapun juga kalau kita gapunya suatu reputasi yang terbaik kita akan kesulitan, untuk itu ita memastikan reputasi kita itu baik agar memudahkan menarik talenta yang terbaik juga."

Irma selaku triangulator dalam peneitian ini mengungkapkan bahwa, sangat penting bagi perusahaan untuk memiliki dan menunjukkan reputasi yang baik kepada masyarakat atau dalam hal ini kepada para peserta.Hal tersebut dimaksudkan untuk mempermudah mereka untuk menarik talenta terbaik yang nantinya dapat bergabung dalam perusahaan mereka.

Dari hasil wawancara peneliti mengenai makna Unilever, peneliti menemukan setiap peserta memiliki makna tersendiri mengenai Unilever. Beberapa informan menyampaikan bahwa Unilever adalah salah satu perusahaan besar yang bergerak dalam bisnis FMCG yang cukup dikenal oleh masyarakat di Indonesia, karena produknya yang tersebar di hampir setiap daerah di Indonesia, baik itu di pasar tradisional, pasar modern, di rumah-rumah masyarakat pun dengan mudah kita dapat menemukan produk dari Unilever.

6 Wawancara dengan Triangulator 4 November 2015
Selain itu juga beberapa peserta mengungkapkan makna mengenai Unilever dari sisi internal perusahaan, beberapa peserta mengatakan bahwa Unilever merupakan perusaaan yang bersifat sustainable dan perusahaan yang peduli lingkungan.Selain itu juga dikatakan bahwa employee dari Unilever merupakan individu yang pekerja keras dan perusahaan dapat mem-fasilitasi karyawannya dengan baik. Apayang diungkapkan peserta diatas sejalan dengan konsep employer branding menurut Estis, serta Minchington, CEO dari Employer Brand Institute yaitu Social Value. Calon karyawan atau yang dalam konteks ini adlah para peserta UFLL akan mempunyai persepsi bahwa lingkungan kerja atau temanteman kerja merupakan tim yang berkualitas serta mempunyai atmosfir yang baik.

Beberapa hal diatas sejalan dengan apa yang dikatakan triangulator

"Well ada beberapa yang menjadi objektif yang menjadi dasar dari kompetisi UFLL ini. Untuk dari Unilever sendiri itu kita ingin memperkenalkan Unilever ke anakanak, sehingga anak-anak bisa mengerti Unilever dari sudut pandang yang lain yaitu dari sudut pandang internal."

Triangulator juga mengatakan Selama UFLL berlangsung ini pihak Unilever juga menanamkan nilai-nilai perusahaan mereka, sehingga para peserta dapat melihat Unilever dari sudut pandang lain yaitu sudut pandang internal perusahaan. Harapan lain dari pihak Unilever adalah nantinya para peserta dapat menjadi ambassador Unilever diantara teman-teman kampusnya, baik itu dalam menyebarkan informasi mengenai Unilever maupun mengenai kompetisi UFLL sendiri. ${ }^{8}$

Sesuai dengan apa yang dikatakan oleh triangulator bahwa kompetisi ini merupakan sebuah bentuk employer branding dari perusahaan, yang dimana hasil akhir dari tujuan ini adalah bergabungnya para peserta ke dalam perusahaan maka peneliti menanyakan makna UFLL sebagai peluang untuk meneruskan karir di Unilever. Dari hasil wawancara kepada enam peserta UFLL, peneliti menemukan bahwa setiap informan memiliki makna tersendiri.Makna tersebut merupakan makna afirmatif, relative, bahkan negatif.

7 Wawancara dengan Triangulator 4 November 2015 8 Wawancara dengan Triangulator 4 November 2015 
Pertama adalah makna afirmatif, yaitu berarti makna yang disampaikan oleh informan menyatakan setuju dengan pernyataan bahwa UFLL merupakan peluang untuk mereka meneruskan karirdi Unilever. Menurutinforman yang memiliki makna afirmatif beranggapan bahwa, setiap peserta bisa untuk meneruskan karir di Unilever, hal tersebut disebabkan karena para peserta tentu telah memiliki pengetahuan lebih mengenai Unilever karena mereka telah mengikuti kompetisi UFLL. Beberapa dari peserta juga mengungkapkan bahwa dari awal mereka memang ingin bergabung dengan Unilever.

Makna yang kedua adalah makna yang bersifat relative, di mana beberapa peserta menganggap bahwa pernyataan mengenai UFLL merupakan peluang untuk meneruskan karir di Unilever tidak sepenuhnya benar namun juga tidak sepenuhnya salah. Mereka mengatakan bahwa tidak sepenuhnya peserta-peseta UFLL memiliki keinginan untuk bergabung lebih lanjut dengan Unilever. Ada beberapa dari peserta yang memilih menekuni hal lain setelah mereka lulus dari tempatnya berkuliah saat ini. Mereka juga berpendapat bahwa peserta yang mengikuti kompetisi UFLL lebih kepada ingin mendapatkan pengalaman berkompetisi, bukan karena ingin bergabung dengan Unilever.

Triangulator pun menyampaikan pendapatnya menegnai pernyataan tersebut yaitu

"Oh kalau dari peluang kita bisa katakan sama saja. Karena mereka juga melewati step yang sama dengan mereka yang bukan peserta UFLL. Tapi kelebihan mereka adalah mereka dapat mengenal Unilever dari dalamnya bagaimana dan orang seperti apa yang dibutuhkan oleh Unilever."

Makna yang ketiga adalah makna yang berssifat negative di mana makna tersebut disampaikan oleh beberapa informan yang cenderung tidak setuju dengan pernyataan bahwa UFLL merupakan peluang untuk meneruskan karir di Unilever. Peserta meng-ungkapkan bahwa UFLL hanya memberikan pengalaman nyata bagaimana rasanya bekerja di dalam Unilever, bukan memberikan janji mengenai karir di masa mendatang.Selain itu, seperti yang telah diungkapkan bahwa beberapa dari peserta yang mengikuti UFLL hanya ingin mendapatkan pengalaman mengenai dunia bisnis maupun pengalaman berkompetisi.

Makna merupakan kecenderungan untuk bereaksi terhadap suatu bentuk bahasa.Pemaknaan lebih menuntut kemampuan integratif manusia. Pancaindra, daya pikir, dan akal budinya memiliki peranan. Menurut fenomenologi transcendental Edmund Husserl, Apa yang diketahui seseorang dianggap merupakan apa yang telah dialami orang tersebut. Stanley Deetz (Littlejohn dan Foss, 2009:57), mengemukakan tiga prinsip dasar fenomenologi:

1. Pengetahuan adalah kesadaran. Pengetahuan tidak disimpulkan dari pengalaman namun ditemukan secara langsung dari pengalaman sadar.

2. Makna dari sesuatu terdiri atas potensi sesuatu itu pada hidup seseorang. Dengan kata lain, bagaimana seseorang memandang suatu objek bergantung pada makna objek itu baginya.

3. Bahasa adalah "kendaraan makna". Kita mendapatkan pengalaman melalui bahasa yang digunakan untuk mendefinisikan dan menjelaskan dunia kita.

Kompetisi Unilever Future Leaders League sendiri merupakan sebuah kompetisi bisnis yang diadakan oleh Unilever guna menciptakan ataupun membentuk generasi muda sebagai pribadi-pribadi yang berkarakter dan berkualitas di masa mendatang.

"Oleh karena itu kita menarik talenta-talenta terbaik di Universitas masing-masing dan juga salah satu cara kita membangun talenta terbaik Indonesia. Karena bagaimanapun juga, kompetisi kita akan berlangusng di global sehingga anak-anak Indonesia dapat bersaing dengan luar negeri.",9

Makna yang diungkapkan oleh para peserta mengenai kompetisi UFLL ini pun beragam.Adapun makna UFLL bagi para informan adalah sebagai berikut:

1. Senada dengan apa yang diungkapkan oleh Mbak Irma diatas, salah satu informan dan peserta bernama Edwin mengatakan bahwa UFLL ini merupakan tempat pembentukan karakter bagi dirinya. Makna tersebut ia dapat karena pengalaman yang ia rasakan dari berbagai kegiatan selama

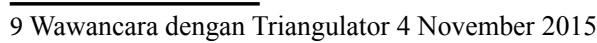


UFLL berlangsung. Mentoring pribadi contohnya, dimana sebelum diberikan kasus mengenai bisnis, para Unilever leaders akan menjelaskan tentang kasus tersebut dan menceritakan pengalaman mereka selama bekerja di Unilever.

2. Sebagian peserta juga mengatakan bahwa kompetisi UFLL merupakan pengalaman terbaik bagi mereka. Beberapa dari peserta mengungkapkan bahwa makna yang diungkapkan oleh mereka ini terbentuk karena pengalaman dan manfaat yang mereka rasakan selama UFLL berlangsung. Dalam lima hari kompetisi berlangsung dimana peneliti terlibat dan mengobservasi mereka dari awal kegiatan hingga selesai, terjadi perubahan dalam diri para peserta. Saat awal bergabung mereka terlihat canggung satu dengan yang lain, namun hari demi hari mereka semakin terlihat akrab, hal tersebut bisa disebabkan karena intensitas pertemuan mereka dimana para peserta selalu menjalani kegiatan bersama-sama, baik dalam pengerjaan kasus ataupun acara-acara hiburan yang telah disiapkan oleh Unilever. Bahkan saat kegiatan UFLL selesai diadakan, mereka masih sering menjalin hubungan satu sama lain. Hal tersebut peneliti ketahui dari akun media sosial para peserta.

3. Kompetisi bisnis yang dibuat oleh Unilever ini tidak terasa seperti kompetisi karena dibawakan dan dikemas dengan sangat meyenangkan. Kegiatan-kegiatan dalam UFLL tidak hanya kompetisi bisnis, namun juga terdapat team bonding atau hiburanhiburan dengan tujuan agar para peserta dapat akrab satu dengan yang lain. Karena dalam kompetisi ini, para peserta diwajibkan bekerja dalam satu tim dalam setiap kegiatan. Tujuannya agar para peserta dapat merasakan langsung bagaimana menjadi karyawan dari Unilever yan selalu bekerja dalam sebuah tim. Hal tersebut juga yang mengajarkan mereka mengenai leadership atau kepemimpinan. Seperti bagaimana meng-handle sebuah tim agar dapat bekerja dengan kondusif, mereka juga belajar untuk menjadi pemimpin bagi dirinya sendiri seperti contohnya dapat mengontrol emosi mereka agar tim tetap harmonis.

4. Sebagian peserta juga mengungkapkan dengan gamblang bahwa UFLL ini merupakan langkah awal mereka untuk bekerja di Unilever. Pernyataan tersebut dapat berarti tujuan employer branding dari Unilever sudah menyentuh added value seperti apa yang diungkapkan oleh Estis, serta Minchington, CEO dari Employer Brand Institute, yang dimana salah satu added value dengan membangun employer branding adalah Interest Value. Dengan adanya brand yang baik, maka ketertarikan calon karyawan terhadap merek perusahaan tersebut akan meningkat karena rasa puas serta keinginan untuk bekerja di lingkungan yang dipersepsikan dari brand tersebut. Dalam hal ini, Unilever menjalankan strategi employer branding mereka dengan membuat kompetisi UFLL yang dimana dalam kompetisi tersebut Unilever menanamkan nilai-nilai dari perusahaan kepada para peserta seperti bagaimana menjadi leaders atau pemimpin yang diharapkan oleh Unilever.

5. Makna terakhir yang diungkapkan oleh peserta selanjutnya adalah UFLL sebagai sara transformasi diri mereka. Beberapa dari peserta mengungkapkan bahwa pada awal mereka mengikuti kompetisi ini, tidak terdapat keinginan mereka untuk bergabung lebih lanjut dengan Unilever. Kebanyakan dari mereka hanya ingin mendapatkan pengalaman dan ilmu mengenai kompetisi di bidang bisnis. Namun setelah mengikuti kom-petisi ini, melalui kegiatan-kegiatan yang disiapkan oleh Unilever, peserta telah mendapatkan manfaat yang akhirnya membuat mereka tertarik untuk bergabung bersama Unilever. Selain itu perubahan yang terjadi pada peserta seperti contohnya adalah tentu-nya mereka mendapatkan banyak pelajaran mengenai bisnis khususnya dalam bidang FMCG yang didapat dari kasuskasus maupun mentoring dari karyawan Unilever. Mereka juga belajar mengenai kemepimpinan secara tidak langsung dari kegiatan tersebut seperti yang dikatakan oleh John Adair (2007) dalam bukunya Cara Menumbuhkan Pemimpin, bahwa Cara alamiah mempelajari kepemimpinan adalah melakukannya dalam kerja dengan praktik seperti pemagangan pada seorang seniman ahli, pengrajin, atau praktisi. 
Dalam hubungan ini sang ahli diharapkan sebagai bagian dari peranya memberikan pengajaran atau instruksi.

Tradisi fenomenologi berusaha menggambarkan makna dari pengalaman hidup dari beberapa individu mengenai konsep fenomena yang dialaminya.Kaum fenomenologis berusaha mempelajaristruktirkesadarandalampengalaman individu.Salah satu aspek fenomenologi yang banyak dibahas dalam ilmu sosial, khususnya yang berkaitan dengan metodologi penelitian ilmu spsoa; adalah, "pemahaman dari dalam" atau "perspektif perilaku".

Inti pemikiran Schutz adalah bagaimana memahami tindakan sosial melalui penafsiran. Proses penafsiran dapat digunakan untuk memperjelas atau memeriksa makna yang sesungguhnya, sehingga dapat memberikan konsep kepekaan yang implisit. Schutz meletakkan hakikat manusia dalam pengalaman subjektif, terutama ketika mengambil tin-dakan dan mengambilk sikap terhadap dunia kehidupan sehari-hari. Dalam hal ini, Schutz mengikuti penikiran Husserl, yaitu proses pemahaman aktual kegiatan kita, dan pemberian makna terhadapnya, sehingga terhadapnya, sehingga terrefleksi daam tingkah laku (Kuswarno 2009:18).

\section{SIMPULAN}

Makna kegiatan Unilever Future Leaders League yang disampaikan oleh peserta UFLL dapat dimaknai menjadi, UFLL sebagai sebuah kompetisi dan UFLL sebagai peluang untuk meneruskan karir di Unilever. Dimana di dalam kedua makna tersebut terdapat berbagai makna yang diungkapkan oleh para peserta diantaranya UFLL merupakan sarana transformasi diri, tempat pembentukkan karakter, kompetisi yang menyenangkan, pengalamanterbaikyang didapat oleh peserta. Peserta juga meng-ungkapkan jika peserta dapat meneruskan karir di Unilever karena telah mengetehaui Unilever lebih dalam daripada mereka yag tidak mengikuti kompetisi UFLL, namun juga hal tersebut tergantung dari keinginan masing-masing peserta. Dengan didakannya kegiatan UFLL yang notabene merupakan sebuah kompetisi bisnis dengan tujuan membangun jiwa kepemimpinan dan sebuah bentuk employer branding dari Unilever Indonesia, peserta kompetisi diharapakan dapan menjadi individu-individu yang bersaing baik dalam skala nasional maupun internasional. Juara dalam kompetisi UFLL Indonesia ini nantinya akan dilombakan dalam UFLL global yang bertaraf internasional. Bentuk employer branding yang dilakukan oleh Unilever dalam kegiatan ini bersifat tersirat melalui kegiatankegiatan selama kompetisi berlangsung.Melalui kegiatan tersebut para peserta diharapkan dapat bergabung dengan Unilever sebagai karyawan yang dapat mengembangkan bisnis Unilever lebih lanjut.

Saran yang peneliti berikan adalah: 1) Unilever sebaiknya lebih mengorganisir atau mewadahi para peserta yang telah mengikuti kompetisi UFLL. Karena salah satu harapan dari pihak Unilever sesuai yang diungkapkan oleh triangulator adalah peserta diharapkan menjadi ambassador dari UFLL untuk selanjutnya membagikan pengalaman mereka kepada calon peserta di tahun selanjutnya.Hal tersebut sebaiknya dilakukan agar para calon peserta yang ingin mengikuti UFLL telah mempunyai gambaran dari pengalaman peserta yang telah mengikuti UFLL.(2) Agar tujuan dari UFLL yang merupakan salah satu bentuk employer branding dapat tercapai, sebaiknya pihak Unilever menciptakan prosedur khusus untuk melakukan tindakan follow up kepada para peserta. Sehingga nantinya para peserta yang berencana melanjutkan karir mereka di Unilever dapat lebih terakomodasi, termudahkan, dan dapat bertambah jumlahnya. (3) Menurut hasil observasi dari peneliti dan jawaban dari para informan, kompetisi Unilever Future Leaders League yang memiliki tujuan membangun jiwa kepemimpinan ini pada kenyataannya tidak dapat kegiatan khusus selama kompetisi berlangsung untuk meme-nuhi tujuan tersebut. Maka dari itu sebaiknya Unilever menambahkan kegiatan khusus untuk membangun jiwa kepemimpinan peserta di dalam kompetisi UFLL.

\section{DAFTAR PUSTAKA}

Creswell, John W. 2007. Qualitative Inquiry and Research Design: Choosing among five approaches. London: Sage Publications Ltd.

Hasanudin, Dani R dan Tedi Ruhiyat. 2006. Budaya, Bahasa, Semiotika: Sebuah. Catatan Kecil. Bandung: Balatin Pratama. 
Kuswarno, Engkus. 2009. Metodologi Penelitian Komunnikasi Fenomenologi Konsepsi, Pedoman, dan Contoh Penelitian. Bandung: Widya Padjadjaran.

Moleong, Lexy J. 2009. Metodologi Penelitian Kualitatif. Bandung: PT Remaja Rosdakarya.
Mulyana, Deddy. 2007. Ilmu Komunikasi Suatu Pengantar. Bandung: PT Remaja Rosdakarya.

Sobur, Alex. 2009. Semiotika Komunikasi. Bandung: PT Remaja Rosdakarya. 